\title{
Front Matter: Volume 10508
}

, "Front Matter: Volume 10508," Proc. SPIE 10508, Reporters, Markers, Dyes, Nanoparticles, and Molecular Probes for Biomedical Applications X, 1050801 (7 May 2018); doi: 10.1117/12.2323116

SPIE. Event: SPIE BiOS, 2018, San Francisco, California, United States 


\section{PROGRESS IN BIOMEDICAL OPTICS AND IMAGING}

\section{Reporters, Markers, Dyes, Nanoparticles, and Molecular Probes for Biomedical Applications $X$}

Samuel Achilefu

Ramesh Raghavachari

Editors

29-30 January 2018

San Francisco, California, United States

Sponsored and Published by

SPIE 
The papers in this volume were part of the technical conference cited on the cover and title page. Papers were selected and subject to review by the editors and conference program committee. Some conference presentations may not be available for publication. Additional papers and presentation recordings may be available online in the SPIE Digital Library at SPIEDigitallibrary.org.

The papers reflect the work and thoughts of the authors and are published herein as submitted. The publisher is not responsible for the validity of the information or for any outcomes resulting from reliance thereon.

Please use the following format to cite material from these proceedings:

Author(s), "Title of Paper," in Reporters, Markers, Dyes, Nanoparticles, and Molecular Probes for Biomedical Applications X, edited by Samuel Achilefu, Ramesh Raghavachari, Proceedings of SPIE Vol. 10508 (SPIE, Bellingham, WA, 2018) Seven-digit Article CID Number.

ISSN: 1605-7422

ISSN: 2410-9045 (electronic)

ISBN: 9781510615014

ISBN: 9781510615021 (electronic)

Published by

SPIE

P.O. Box 10, Bellingham, Washington 98227-0010 USA

Telephone +1 3606763290 (Pacific Time) · Fax +1 3606471445

SPIE.org

Copyright (C) 2018, Society of Photo-Optical Instrumentation Engineers.

Copying of material in this book for internal or personal use, or for the internal or personal use of specific clients, beyond the fair use provisions granted by the U.S. Copyright Law is authorized by SPIE subject to payment of copying fees. The Transactional Reporting Service base fee for this volume is $\$ 18.00$ per article (or portion thereof), which should be paid directly to the Copyright Clearance Center (CCC), 222 Rosewood Drive, Danvers, MA 01923. Payment may also be made electronically through CCC Online at copyright.com. Other copying for republication, resale, advertising or promotion, or any form of systematic or multiple reproduction of any material in this book is prohibited except with permission in writing from the publisher. The CCC fee code is 1605$7422 / 18 / \$ 18.00$.

Printed in the United States of America.

Publication of record for individual papers is online in the SPIE Digital Library.

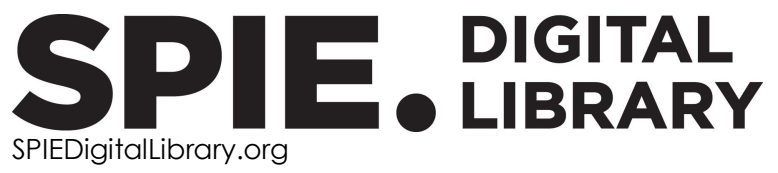

Paper Numbering: Proceedings of SPIE follow an e-First publication model. A unique citation identifier (CID) number is assigned to each article at the time of publication. Utilization of CIDs allows articles to be fully citable as soon as they are published online, and connects the same identifier to all online and print versions of the publication. SPIE uses a seven-digit CID article numbering system structured as follows:

- The first five digits correspond to the SPIE volume number.

- The last two digits indicate publication order within the volume using a Base 36 numbering system employing both numerals and letters. These two-number sets start with 00, 01, 02, 03, 04, 05, 06, 07, 08, 09, OA, OB ... 0Z, followed by 10-1Z, 20-2Z, etc. The CID Number appears on each page of the manuscript. 


\title{
Contents
}

\author{
$\checkmark$ Authors \\ vii Conference Committee
}

THERANOSTICS AND NIR FLUORESCENCE IMAGING STRATEGIES

1050803 Clinically translatable nanotheranostic platforms for peripheral nerve regeneration: design with outcome in mind [10508-7]

1050805 Dual-radiolabeled nanoparticle probes for depth-independent in vivo imaging of enzyme activation [10508-22]

1050806 Red and near-infrared fluorophores inspired by chlorophylls: consideration of practical brightness in multicolor flow cytometry and biomedical sciences (Invited Paper) [10508-26]

MOLECULAR AND PHYSIOLOGICAL IMAGING STRATEGIES AND PROBES

1050809 Effect of linkers on the $a_{v} \beta_{3}$ integrin targeting efficiency of cyclic RGD-conjugates [10508-25]

\section{NANOIMAGING PLATFORMS}

10508 OG Ultrasmall visible-to-near-infrared emitting silver-sulfide quantum dots for cancer detection and imaging [10508-21]

$10508 \mathrm{OH}$ Toxicological evaluation of Cd-based fluorescent nanoprobes by means of in vivo studies [10508-6]

\section{POSTER SESSION}

10508 OK The deflection of carbon composite carbon nanotube / graphene using molecular dynamics simulation [10508-13]

$10508 \mathrm{OL}$ Mechanical properties of oxygen-doped porous carbon nanostructures [10508-14]

10508 OM Control method conductive properties ZnS quantum dots [10508-15]

$10508 \mathrm{ON}$ Pillared graphene on the basis of zigzag carbon nanotubes for adsorption in medicine: mechanical properties [10508-16]

10508 OP Perspectives of graphene-nucleotide complexes for the development of new bioelectronics devices [10508-18] 
$105080 Q$ In silico study of liposome transport across biomembranes [10508-19]

10508 OR Investigation of the mechanism for penetration of low density lipoprotein into the arterial wall [10508-20] 


\section{Authors}

Numbers in the index correspond to the last two digits of the seven-digit citation identifier (CID) article numbering system used in Proceedings of SPIE. The first five digits reflect the volume number. Base 36 numbering is employed for the last two digits and indicates the order of articles within the volume. Numbers start with 00, 01, 02, 03, 04, 05, 06, 07, 08, 09, OA, OB...0Z, followed by 10-1Z, 20-2Z, etc.

Achilefu, Samuel, 05, 09, 0G

Akers, Walter J., 05

Al-Yasiri, Amal Y., 05

Black, Kvar C. L., 05

Brody, Steven L., 05

Cutler, Cathy S., 05

Du, Hai, 06

Farias, Patricia M. A., $\mathrm{OH}$

Glukhova, O. E., OP, OQ, OR

Glukhovskoy, Evgeny G., OM

Gorantla, Vijay S., 03

Grabowska, Dorota, 09

Gunsten, Sean P., 05

Hennkens, Heather M., 05

$\mathrm{Hu}$, Gongfang, $\mathrm{O6}$

Janjic, Jelena M., 03

Karmakar, Partha, 09

Kirillova, I. V., OK

Kolesnikova, Anna S., OK, OL, OM, ON

Kossovich, L. U., OK

Kuchuk, Maryna, 05

Laforest, Richard, 05

Landsiedel, Robert, $\mathrm{OH}$

Liang, Kexian, 05

Lindsey, Jonathan S., 06

Liu, Rui, 06

Ma-Hock, Lan, $\mathrm{OH}$

Mazepa, Margarita M., ON

Prikhodchenko, Kristina A., OL

Sanyal, Nibedita, 09

Sarder, Pinaki, 05

Shen, Duanwen, OG

Shinkarenko, Oksana A., OM

Shmygin, D. S., OP

Slepchenkov, M. M., OQ, OR

Sudlow, Gail, 09, 0G

Tang, Rui, OG

Taniguchi, Masahiko, 06

van Ravenzwaay, Bennard, $\mathrm{OH}$

$\mathrm{Xu}$, Baogang, $0 \mathrm{G}$

Zhou, Mingzhou, 05

Ziabrev, Kostiantyn, 09

Zyktin, A. A., OQ, OR 
Proc. of SPIE Vol. 10508 1050801-6

Downloaded From: https://www.spiedigitallibrary.org/conference-proceedings-of-spie on 26 Apr 2023 Terms of Use: https://www.spiedigitallibrary.org/terms-of-use 


\title{
Conference Committee
}

\author{
Symposium Chairs
}

James G. Fujimoto, Massachusetts Institute of Technology

(United States)

R. Rox Anderson, Wellman Center for Photomedicine, Massachusetts

General Hospital (United States) and Harvard Medical School

(United States)

Program Track Chairs

Paras Prasad, SUNY/Buffalo (United States)

Dan V. Nicolau, McGill University (Canada)

Conference Chairs

Samuel Achilefu, Washington University School of Medicine in St. Louis (United States)

Ramesh Raghavachari, U.S. Food and Drug Administration

(United States)

Conference Program Committee

Mingfeng Bai, Vanderbilt University Medical Center (United States)

Mikhail Y. Berezin, Washington University School of Medicine in

St. Louis (United States)

Richard B. Dorshow, MediBeacon, LLC (United States)

Hisataka Kobayashi, National Cancer Institute (United States)

Ashok Kumar Mishra, Indian Institute of Technology Madras (India)

Gabor Patonay, Georgia State University (United States)

Attila Tarnok, Universität Leipzig (Germany)

Yasuteru Urano, The University of Tokyo (Japan)

Session Chairs

1 Theranostics and NIR Fluorescence Imaging Strategies

Samuel Achilefu, Washington University School of Medicine in St. Louis (United States)

2 Molecular and Physiological Imaging Strategies and Probes

Mikhail Y. Berezin, Washington University School of Medicine in St. Louis (United States) 
3 Nano Materials for Biomedical and Imaging Applications I: Joint Session with Conferences 10508 and 10547

Ramesh Raghavachari, U.S. Food and Drug Administration (United States)

Philip R. Hemmer, Texas A\&M University (United States)

4 Nano Materials for Biomedical and Imaging Applications II: Joint Session with Conferences 10508 and 10547

Philip R. Hemmer, Texas A\&M University (United States)

Ramesh Raghavachari, U.S. Food and Drug Administration (United States)

5 Nano Materials for Biomedical and Imaging Applications III: Joint Session with Conferences 10508 and 10547

Philip R. Hemmer, Texas A\&M University (United States)

Ramesh Raghavachari, U.S. Food and Drug Administration (United States)

$6 \quad$ Nanoimaging Platforms

Ramesh Raghavachari, U.S. Food and Drug Administration (United States)

Samuel Achilefu, Washington University School of Medicine in St. Lovis (United States) 